\title{
Promoting Stenospermic Grape Seed Trace Development and Germination with Plant Growth Regulators
}

\author{
Bruce P. Bordelon ${ }^{1}$ and J.N. Moore ${ }^{2}$ \\ Department of Horticulture and Forestry, University of Arkansas, Fayetteville, AR 72701
}

\begin{abstract}
Additional index words. Vitis spp., seedlessness, fruit breeding
Abstract. Plant growth regulators (PGRs) [antigibberellins (mepiquat chloride, uniconazole, ancymidol, daminozide, chlormequat, ethephon, methazole), cytokinins (BAP, kinetin, BTP, 2iP), and ABA] were evaluated at various concentrations and timings for promotion of seed trace development and germination of four stenospermic grape cultivars (Vitis spp.): 'Venus', 'Mars', 'Reliance', and 'Saturn'. Data include seed trace number per berry, percent of seed traces with endosperm (sinkers), sinker fresh weight, and percent seed trace germination. Several PGRs effectively increased seed number and percent sinkers over control treatments. PGRs had little effect on seed fresh weight and percent germination. PGRs promoted greater increases in percent sinkers than seed number on all cultivars. The number of viable seeds per sample (seed number $\times$ percent sinkers) was increased over controls by up to $802 \%$ on 'Reliance', 239\% on 'Saturn', 154\% on 'Mars', and 153\% on 'Venus'. A moderate percentage of viable seeds from treatments and controls of 'Mars', 'Venus', and 'Saturn' germinated and established normal seedlings. The very small seed traces of 'Reliance' did not germinate from either controls or treatments. The results indicate that PGRs can stimulate seed trace formation in some stenospermic cultivars and therefore may be useful tools in grape breeding programs. Chemical names used: abscisic acid (+/-)cis-trans isomer (ABA); a-cyclopropyl-a-(4-methoxy-phenyl)-5-pyrimidinemethanol (ancymidol); 6benzylaminopurine (BAP); 6-benzylamino-9-(2 tetra-hydropropanyl)-9H-purine (BTP); (2-chloroethyl) trimethyl-ammonium chloride (chlormequat); succinic acid 2,2 dimethyl-hydrazide (daminozide); (2-chloroethyl) phosphonic acid (ethephon); 6-(dimethyl-allylamino) purine (2iP); 6-furfurylaminopurine (kinetin); $N, N$-dimethyl-piperidinium chloride (mepiquat chloride); [2-(3,4-dichlorophenyl)-4-methyl-1,2,4-oxadiazolidine-3,5-dione](methazole); E-1-(4-chlorophenyl)4,4-di-methyl-2-(1,2,4-triazol-1-yl)-1-pentan-3-ol (uniconazole).
\end{abstract}

Seedless table grapes are characterized by stenospermocarpy, a genetically controlled condition in which seed development ceases soon after fertilization, resulting in the formation of partially developed seeds or seed traces (Stout, 1936). Incomplete seed development is due to endosperm breakdown and embryo abortion caused by physiological conditions brought on by high levels of growth-promoting phytohormones at or near bloom (Coombe, 1960; Iwahori et al., 1968; Nitsch et al., 1960).

Breeding for seedlessness has been practiced since the 1870 s by using stenospermic genotypes as males in crosses with seeded females (Ledbetter and Ramming, 1989). This traditional method of breeding seedless grapes requires the use of a seeded female parent to obtain seed for the next generation. Although this approach has been successful, efficiency is low because only a small percentage of segregates within progenies will be seedless (Loomis and Weinberger, 1979; Weinberger and Harmon, 1964) and it requires using a seeded genetic bridge to combine complementary characteristics of seedless types (Ramming, 1990). Recently, embryo culture has been used in grape breeding to germinate the embryos from stenospermic seed for directly hybridizing seedless types (Emershad and Ramming, 1984; Spiegel-Roy et al., 1985). Results indicate that much higher proportions of seedless segregates may be obtained within progenies (Ramming, 1990). However, embryo culture is not without faults. The cost of establishing a sterile laboratory facility is high, seedling production is relatively low, and well-trained personnel are required.

Received for publication 20 Sept. 1993. Accepted for publication 21 Jan. 1994. The cost of publishing this paper was defrayed in part by the payment of page charges. Under postal regulations, this paper therefore must be hereby marked advertisement solely to indicate this fact.

${ }^{1}$ Assistant professor; Dept. of Horticulture, Purdue Univ., West Lafayette, IN 47907-1165.

${ }^{2}$ Distinguished professor.
Synthetic plant growth regulators (PGRs) have been used extensively in grapes, commercially and in research, to modify various aspects of fruiting and vegetative growth of plants (Considine, 1983). Gibberellic acid has been commonly used on seedless table grapes to reduce berry set within clusters, increase berry size, and reduce seed trace size (Considine, 1983; Ledbetter and Ramming, 1989; Weaver, 1972). Conversely, growth retardants, or antigibberellins, have been used to increase berry set in seeded and seedless cultivars (Considine and Coombe, 1972; Coombe, 1965; Pool, 1982; Tukey and Fleming, 1967; Weaver et al., 1962) and promote seed development in stenospermocarpic berries (Ledbetter et al., 1989). Cytokinins have been used to convert male vines to hermaphroditic vines (Moore, 1970; Negi and Olmo, 1966), promote seed development in stenospermic types (Milyaeva et al., 1984), induce flowering and fruit set in seedling vines (Srinivasan and Mullins, 1981), and convert tendrils into inflorescences, in vivo (Srinivasan and Mullins, 1979) and in vitro (Srinivasan and Mullins, 1978). Ethephon, an ethylene generator, has also been used to convert male vines to hermaphroditic vines (Kender and Remaily, 1970) and promote seed development in stenospermic types (Kender and Remaily, 1970; Milyaeva et al., 1984).

This research was initiated to evaluate the use of PGRs on stenospermic grapes for promoting seed trace development. Ideally, in stenospermic genotypes, PGR treatment would lead to the formation of fully developed seeds that could be directly germinated without embryo culture. Such a process would allow hybridization of seedless genotypes and production of viable seed on the vine, saving time and reducing costs. Increase in seed number or percent sinkers would increase the number of viable seeds available for direct germination or embryo culture and would improve efficiency by reducing the number of emasculations needed per cross. 


\section{Materials and Methods}

Various PGRs (antigibberellins, cytokinins, ethephon, ABA) were tested for their promotion of seed trace development in four stenospermic cultivars having a range of seed trace types. 'Venus' has a moderately large, soft seed trace; 'Saturn' has a medium size trace, with moderate hardening (sclerification) of the seed coat; 'Mars' has a small, hardened seed trace; and 'Reliance' has a small, soft seed trace.

Seed trace development was evaluated by determining the number of ovules per berry that developed into seed traces and the relative endosperm development in those seed traces. All seed traces were separated into two categories: sinkers and floaters. Seed traces with intact endosperm sank in water (sinkers), whereas those in which endosperm breakdown had occurred had an empty seed cavity and floated on the surface (floaters). Ovules that did not develop into seed traces remained rudimentary and were not counted. Seed traces that contained an intact endosperm (sinkers) were considered potentially viable, whereas those in which endosperm failed to develop or had broken down (floaters) were considered nonviable.

Data were collected from samples of two to 10 clusters from each treatment, harvested at fruit maturity, and include 1) seed trace number per 50-berry sample, 2) percentage of sinkers, 3) fresh weight of sinkers, and 4) percent germination of sinkers. Fifty berries were selected randomly from the cluster samples and seed traces were collected. Floaters were counted and discarded; sinkers were counted, blotted dry, and weighed to determine fresh weight.

Preliminary experiments were performed in 1988 to develop the PGR application method and germination procedures and to evaluate potential phytotoxicity. The only phytotoxicity noted was with ethephon and ABA, which each caused partial cluster stem necrosis and reduced berry set. PGR application method was chosen to minimize any phytotoxicity that might occur due to whole-vine sprays. PGRs were applied to clusters only with handheld spray bottles using a shield to avoid contact with foliage. All PGR solutions were prepared on the day of application in deionized (DI) $\mathrm{H}_{2} \mathrm{O}$ with $0.1 \%$ Tween 20 as a surfactant. Control treatments consisted of DI $\mathrm{H}_{2} \mathrm{O}$ with $0.1 \%$ Tween 20. Preliminary tests were performed with 'Venus' seed traces to develop sterilization, stratification, and germination procedures. The method used in this study was chosen because it allowed direct germination of seed traces, good control of contamination, and ease of observation for data collection. Germination percentages of test seed lots were generally $<10 \%$, but the technique was deemed adequate for comparison among PGR treatments and no further refinement of the technique was attempted. Sinkers were surfaced-sterilized with $0.26 \%$ sodium hypochlorite (5\% Chlorox) for $5 \mathrm{~min}$, folded into Whatman no. 1 filter paper moistened with a $1000 \mathrm{ppm}$ benomyl solution, then placed in Whirlpak sterile plastic bags for stratification in a dark refrigerator at 4C for 9 weeks in 1989 and 14 weeks in 1990. After stratification, traces were surface-sterilized as before and placed on sterile seed blotter paper (Anchor Paper Co., St. Paul, Minn.) in standard $15 \times 100-\mathrm{mm}$ plastic petri plates for germination tests. Seeds were germinated in a dark incubator with 12-h alternating cycles of 18 and 27C for 6 weeks. Germinated seeds were removed weekly, and seedlings were transplanted into milled sphagnum peat and moved to a heated greenhouse for observation.

Data were analyzed using SAS's GLM procedures. Weighted analysis was performed on percent data and the means were separated with SAS's LSMEANS. Differences in means were determined at $P=0.05$ from LSMEANS PDIFF tables (multiple $t$ tests) or by LSD at $P=0.05$.

Four different experiments were conducted during the 1989 and 1990 seasons. Experiments were conducted on 'Venus', 'Mars', 'Reliance', and 'Saturn' in 1989. Due to winter injury and spring frosts, only 'Venus' plots were used in 1990. All plots were balanced pruned to $30+10$ buds and received standard pest control practices and supplemental irrigation.

Experiment 1. This experiment was designed to determine the effects of a prebloom PGR treatment on seed set induction and the effects of a postbloom application of cytokinins on the promotion of endosperm development. Tests were conducted on mature 'Venus' vines. Initial treatments consisted of five PGRs (chlormequat, daminozide, ethephon, mepiquat chloride, and methazole) applied at two rates each (100 and $1000 \mathrm{ppm})$, another PGR (ancymidol) at a single rate (100 ppm), and one control, for a total of 12 treatments. Each PGR-rate combination was applied to a single vine with four replicates of each treatment completely randomized among vines. PGRs were applied to all clusters on each plant on 29 Apr. 1989, $\approx 2$ weeks prebloom, to coincide with flower differentiation. Two cytokinins (BAP and kinetin) were applied to two randomly chosen basal clusters per plant at 1000 ppm on 16 May $1989, \approx 1$ week postbloom, to coincide with endosperm development. Fruit were harvested at maturity on 25 July 1989. The results were analyzed as a split-plot design with the 12 initial PGR-rate treatments as main plots and the cytokinin treatments as subplots.

Experiment 2. The effects of postbloom applications of cytokinins on seed trace development were tested. BAP and kinetin were applied at three rates each $(250,500,1000 \mathrm{ppm})$ with one control and four replications to mature 'Venus' and 'Saturn' vines on 25 May and 7 June 1989, respectively, $\approx 3$ weeks postbloom. The seven treatments were randomly assigned to half-plant plots. Plants were divided into right and left sides of the trunk, with treatments randomly assigned to one side or the other. Fruit were harvested at maturity: 'Venus' on 25 July, 'Saturn' on 9 Aug. Results were analyzed as a completely randomized design, with each cytokinin-rate a separate treatment.

Experiment 3 . The effects of antigibberellin treatment on different cultivars were evaluated. Three antigibberellins (ancymidol, daminozide, and chlormequat) were applied at two rates each (250 and $500 \mathrm{ppm}$ for daminozide and chlormequat; 50 and $100 \mathrm{ppm}$ for ancymidol) with one control and four replications on 'Mars', 'Reliance', and 'Saturn' vines. Vines were planted in a randomized complete-block design, with one plant of each cultivar occurring in three-plant plots replicated four times. Treatments were assigned randomly to the plots within each block; cultivars were split-plots within each plot; rates were randomly assigned to half of each vine, the right or left side of the trunk, making a split-splitplot design. PGRs were applied on 5 May 1989, $\approx 2$ weeks prebloom. Fruit were harvested on 10 Aug. 1989 at or near maturity for all cultivars. Results were analyzed as a randomized-block split-splitplot design.

Experiment 4. The effects of concentration and number of PGR applications were evaluated. Ten PGRs (five antigibberellins, four cytokinins, and ABA) were applied at two concentrations each and two applications each with one control treatment for a total of 41 treatment combinations with six replications in a randomized complete-block design on mature 'Venus' vines. Each PGR was randomly assigned to a vine within each block. Rates of each PGR were assigned to half of each vine, the right or left side of the trunk. PGRs were applied initially (1x) to all clusters on each half-vine plot on 4 May 1990, $\approx 2$ weeks prebloom, and a second time $(2 \mathrm{x})$ 
to the previously treated clusters of a single shoot within each halfvine plot on 22 May $1990, \approx 1$ week postbloom. Fruit were harvested on 24 July 1990. Rates were chosen as high and low levels for each PGR. Chlormequat, uniconazole, mepiquat chloride, daminozide, kinetin, and BAP were applied at 2000 and 1000 ppm; BTP and 2iP were applied at 100 and 10 ppm; ABA was applied at 10 and $1 \mathrm{ppm}$; and ancymidol was applied at 264 and 132 ppm. Multiple applications were chosen to determine the effects of PGRs during ovule development and embryo-endosperm development stages. Data were analyzed as a split-split-plot design, with PGR as main effects, concentrations of PGR as subplots, and number of applications as sub-subplots.

\section{Results and Discussion}

Treatment effectiveness for promoting seed development can be measured as percentage increase over controls in seed number, percent sinkers, seed trace fresh weight, or percent germination. From a practical standpoint for breeding program efficiency, the best measure of treatment effectiveness would be the number of plants produced from a given seed lot. This value is obtained by multiplying seed number by percent sinkers to obtain the viable seed number and multiplying this value by percent germination to obtain the number of plants produced. However, since percent germination was not affected substantially by PGRs, the viable seed number obtained per sample is considered to be the best measure of treatment effectiveness in this study. Although a percentage of seeds from all treatments on three of the four cultivars tested germinated, conditions for these tests were probably not optimal, and improvements in the techniques should lead to increased percent germination.

Experiment 1. This experiment was designed to test effects of antigibberellins and cytokinins when applied in tandem. Most antigibberellin treatments without follow-up cytokinin treatments resulted in greater seed number, percent sinkers, and sinker fresh weight than the control treatment (Table 1). The most effective among the antigibberellin treatments for seed number were chlormequat and mepiquat chloride at $1000 \mathrm{ppm}$, which each gave an $18 \%$ increase over control. Effective treatments for increasing percent sinkers were chlormequat and daminozide at 1000 and 100 ppm, ethephon and mepiquat chloride at $100 \mathrm{ppm}$, and methazole at 1000 ppm, which gave about a $23 \%$ increase over control. The best treatment for increasing viable seed number was chlormequat at $1000 \mathrm{ppm}$, which gave a 50\% increase over control. Several treatments gave increases of $>30 \%$ over control. Antigibberellin treatments most effective at increasing sinker fresh weight were chlormequat, ethephon, and mepiquat chloride at 100 and 1000 ppm and daminozide at $1000 \mathrm{ppm}$.

Treatments with antigibberellins followed by cytokinins were not expected to affect seed number, as that character should have been established before cytokinin treatment (1 week postbloom). However, there was a decrease in seed number in several cases (data not shown). In no case was seed number greater in the antigibberellin plus cytokinin treatments than the antigibberellinonly treatments. Applying cytokinins postbloom was expected to increase sinker fresh weight and percentage. This was also not the case, as most of the antigibberellin plus cytokinin treatments were either not different or less than antigibberellin-only treatments for these two variables (data not shown). Percent germination for treatments of antigibberellin-only and antigibberellin plus cytokinin were not different from the control in Expt. 1.

Experiment 2. Applying cytokinins postbloom resulted in increases over the control for seed number and percent sinkers for both cultivars and sinker fresh weight on 'Saturn' (Table 2). Percent germination of either cultivar was not different from the control. The most effective cytokinin treatments for seed number on 'Venus' were kinetin at $250 \mathrm{ppm}$ and BAP at 1000 and $250 \mathrm{ppm}$ ( $10 \%$ to $16 \%$ over the control). The most effective treatment for seed number on 'Saturn' was BAP at 1000 ppm (34\% over the control). All cytokinin treatments effectively increased percent sinkers on 'Venus' (up to $25 \%$ over the control) and on 'Saturn' (up to $153 \%$ over the control). Sinker fresh weight of 'Saturn' was increased most by kinetin at 500 ppm (30\% over the control).

Seed number and percent sinkers were affected by cytokinin treatments to a greater extent for 'Saturn' than for 'Venus' in terms of percentage increase over the control. The average effectiveness in terms of viable seed number across all treatments on 'Venus' was a $32 \%$ increase over the control, and on 'Saturn' a $151 \%$

Table 1. Effects of antigibberellins on seed trace development and germination of 'Venus' grapes.

\begin{tabular}{|c|c|c|c|c|c|}
\hline $\begin{array}{l}\mathrm{PGR}^{\mathrm{z}} \\
(\mathrm{ppm})\end{array}$ & $\begin{array}{l}\text { Seed traces } \\
\text { per } 50 \\
\text { berries } \\
(\text { no. })^{\mathrm{y}}\end{array}$ & $\begin{array}{l}\text { Sinkers } \\
(\text { no. })^{\mathrm{x}}\end{array}$ & $\begin{array}{l}\text { Sinker } \\
\text { fresh wt } \\
(\mathrm{mg})^{\mathrm{y}}\end{array}$ & $\begin{array}{l}\text { Germination } \\
(\%)^{\mathrm{x}}\end{array}$ & $\begin{array}{c}\text { Viable seeds } \\
\text { per } 50 \\
\text { berries } \\
(\text { no. })^{\mathrm{w}}\end{array}$ \\
\hline Chlormequat (1000) & $127.5 \mathrm{a}$ & $80.0 \mathrm{a}$ & $27.4 \mathrm{abc}$ & $6.2^{\mathrm{NS}}$ & 102 \\
\hline Chlormequat (100) & $122.8 \mathrm{a}-\mathrm{d}$ & $76.0 \mathrm{abc}$ & $30.0 \mathrm{a}$ & 5.9 & 93 \\
\hline Ethephon (1000) & $114.5 \mathrm{de}$ & $67.9 \mathrm{e}$ & $31.4 \mathrm{a}$ & 4.2 & 78 \\
\hline Ethephon (100) & $117.3 \mathrm{bcd}$ & $78.3 \mathrm{a}$ & $28.6 \mathrm{ab}$ & 7.0 & 92 \\
\hline Daminozide (1000) & $125.5 \mathrm{ab}$ & $77.3 \mathrm{ab}$ & $27.8 \mathrm{abc}$ & 8.8 & 97 \\
\hline Daminozide (100) & $115.3 \mathrm{cde}$ & $78.3 \mathrm{a}$ & $25.2 \mathrm{bc}$ & 9.8 & 90 \\
\hline Ancymidol (100) & $124.5 \mathrm{ab}$ & $72.7 \mathrm{bcd}$ & $25.6 \mathrm{bc}$ & 3.4 & 91 \\
\hline Mepiquat chloride (1000) & $127.8 \mathrm{a}$ & $68.9 \mathrm{de}$ & $27.5 \mathrm{abc}$ & 7.1 & 88 \\
\hline Mepiquat chloride (100) & $123.5 \mathrm{abc}$ & $76.1 \mathrm{ab}$ & $27.6 \mathrm{abc}$ & 10.4 & 94 \\
\hline Methazole (1000) & $120.8 \mathrm{a}-\mathrm{d}$ & $76.4 \mathrm{ab}$ & $24.1 \mathrm{~cd}$ & 8.3 & 92 \\
\hline Methazole (100) & $117.5 \mathrm{bcd}$ & 71.7 cde & $23.7 \mathrm{~cd}$ & 3.9 & 84 \\
\hline Control & $108.5 \mathrm{e}$ & $63.1 \mathrm{f}$ & $20.7 \mathrm{~d}$ & 6.9 & 68 \\
\hline
\end{tabular}

${ }^{\mathrm{Z}} \mathrm{PGR}=$ plant growth regulator; treatments were applied 2 weeks prebloom.

'Mean separation within columns by LSD at $P=0.05$.

xPercent data are weighted least squares means separated by multiple $t$ tests at $P=0.05$.

${ }^{\mathrm{w}}[($ Seed traces per 50 berries $\times$ percent sinkers $) / 100]$.

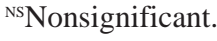


Table 2. Effects of cytokinins (BAP and kinetin) on seed trace development and germination of 'Venus' and 'Saturn' grapes.

\begin{tabular}{|c|c|c|c|c|c|}
\hline $\begin{array}{l}\text { Cytokinin }^{z} \\
(\mathrm{ppm})\end{array}$ & $\begin{array}{l}\text { Seed traces } \\
\text { per } 50 \\
\text { berries } \\
(\text { no. })^{\mathrm{y}}\end{array}$ & $\begin{array}{l}\text { Sinkers } \\
(\%)^{\mathrm{x}}\end{array}$ & $\begin{array}{l}\text { Sinker } \\
\text { fresh wt } \\
(\mathrm{mg})^{\mathrm{y}}\end{array}$ & $\begin{array}{l}\text { Germination } \\
(\%)^{\mathrm{x}}\end{array}$ & $\begin{array}{c}\text { Viable seeds } \\
\text { per } 50 \\
\text { berries } \\
(\text { no. })^{\mathrm{w}}\end{array}$ \\
\hline \multicolumn{6}{|c|}{ Venus } \\
\hline BAP (1000) & $116.3 \mathrm{a}$ & $77.2 \mathrm{ab}$ & $25.4^{\mathrm{NS}}$ & $5.9^{\mathrm{NS}}$ & 90 \\
\hline $\mathrm{BAP}(500)$ & $100.8 \mathrm{c}$ & $77.4 \mathrm{ab}$ & 24.6 & 4.5 & 78 \\
\hline $\mathrm{BAP}(250)$ & $116.5 \mathrm{a}$ & $79.2 \mathrm{a}$ & 25.9 & 5.4 & 92 \\
\hline Kinetin (1000) & $114.8 \mathrm{ab}$ & $78.2 \mathrm{a}$ & 27.8 & 4.1 & 90 \\
\hline Kinetin (500) & $115.3 \mathrm{ab}$ & $74.6 \mathrm{~b}$ & 28.7 & 3.2 & 86 \\
\hline Kinetin (250) & $121.8 \mathrm{a}$ & $76.0 \mathrm{ab}$ & 26.0 & 3.2 & 93 \\
\hline Control & $105.5 \mathrm{bc}$ & $63.3 \mathrm{c}$ & 21.9 & 3.4 & 67 \\
\hline$P>\mathrm{F}$ & \multicolumn{4}{|c|}{ Saturn } & \\
\hline BAP (1000) & $151.5 \mathrm{a}$ & $65.0 \mathrm{a}$ & $18.4 \mathrm{abc}$ & $9.9^{\mathrm{NS}}$ & 98 \\
\hline BAP (500) & $120.0 \mathrm{~cd}$ & $60.0 \mathrm{ab}$ & $18.1 \mathrm{abc}$ & 10.1 & 72 \\
\hline $\mathrm{BAP}(250)$ & $131.0 \mathrm{bcd}$ & $57.1 \mathrm{ab}$ & $19.1 \mathrm{ab}$ & 7.4 & 75 \\
\hline Kinetin (1000) & $125.3 \mathrm{bcd}$ & $52.3 \mathrm{~b}$ & $16.9 \mathrm{bcd}$ & 10.7 & 66 \\
\hline Kinetin (500) & $138.0 \mathrm{ab}$ & $54.2 \mathrm{~b}$ & $20.3 \mathrm{a}$ & 8.4 & 75 \\
\hline Kinetin (250) & $123.8 \mathrm{~cd}$ & $41.6 \mathrm{c}$ & $16.8 \mathrm{~cd}$ & 11.2 & 52 \\
\hline Control & $113.0 \mathrm{~d}$ & $25.7 \mathrm{~d}$ & $15.6 \mathrm{~d}$ & 13.8 & 29 \\
\hline$P>\mathrm{F}$ & 0.0014 & 0.0001 & 0.0069 & 0.5441 & \\
\hline
\end{tabular}

Treatments were applied 2 weeks postbloom.

y Mean separation within columns by LSD at $P=0.05$.

xPercent data are weighted least squares means separated by multiple $t$ tests at $P=0.05$.

${ }^{\mathrm{w}}[($ Seed traces per 50 berries $\times$ percent sinkers $) / 100]$.

${ }^{\mathrm{NS} N o n s i g n i f i c a n t .}$

increase over the control. The most effective treatments on viable seed number per sample were BAP and kinetin at $250 \mathrm{ppm}$, which both gave a 38\% increase over the control on 'Venus', and BAP at $1000 \mathrm{ppm}$, which gave a $239 \%$ increase over the control on 'Saturn'.

Experiment 3. Tests involving three antigibberellins at two concentrations applied 2 weeks prebloom on 'Mars', 'Reliance', and 'Saturn' showed that differences occurred among cultivars for traits measured and that cultivar $\times$ treatment interactions were present. Consequently, analysis was conducted separately for each cultivar.

Treatments increased sinker percent and fresh weight but not seed number or percent germination on 'Mars' (Table 3). Treatment effects on percent sinkers were variable with responses, ranging from a decrease of $11 \%$ to an increase of $72 \%$ over control. Sinker fresh weight was increased by ancymidol at $100 \mathrm{ppm}$ and daminozide at $500 \mathrm{ppm}$. The most effective treatment on 'Mars' for viable seed number was daminozide at $250 \mathrm{ppm}$, which gave a $154 \%$ increase over the control.

Treatments increased seed number and percent sinkers but not sinker fresh weight or percent germination on 'Reliance' (Table 3). 'Reliance' had a very low percent sinker value for the control (5\%) compared to the other cultivars studied. The effects of treatments on percent sinkers were dramatic, with responses ranging from $242 \%$ to $572 \%$ increases over control. Seed number was not affected as much, with responses ranging from increases of $1 \%$ to $72 \%$ over the control. The most effective treatment for viable seed number was daminozide at $250 \mathrm{ppm}$, which gave an $802 \%$ increase over the control.

Treatments increased seed number, percent sinkers, and percent germination, but not sinker fresh weight on 'Saturn' (Table 3). Treatments had more effect on percent sinkers than on seed number. The effects of treatments for seed number ranged from a decrease of $10 \%$ to an increase of $14 \%$ over the control. The effects of treatments on percent sinkers ranged from increases of $74 \%$ to $105 \%$ over the control. Two treatments increased percent germination over the control. Chlormequat at $500 \mathrm{ppm}$ resulted in a $90 \%$ increase and ancymidol at $100 \mathrm{ppm}$ resulted in a $92 \%$ increase over the control. The most effective treatment on 'Saturn' in terms of viable seed number was chlormequat at $250 \mathrm{ppm}$, which resulted in a $134 \%$ increase over the control. Daminozide at 250 and 500 ppm also gave $>100 \%$ increases over the control.

Experiment 4. In 1990, a test of 10 PGRs (five antigibberellins, four cytokinins, and $\mathrm{ABA}$ ) at two concentrations each and at either one (1 week prebloom) or two (1 week prebloom plus 1 week postbloom) applications was conducted. Analysis of variance for this experiment indicated that differences in seed number and percent sinkers were significant for the particular combination of PGR, concentration, and number of applications (Table 4). Differences in sinker fresh weight and percent germination were significant only for PGR effects. Consequently, means of seed number and percent sinkers for each treatment $(\mathrm{PGR} \times$ concentration $\times$ number of applications) were separated by multiple $t$ tests with SAS's LSMEANS PDIFF procedure at $P=0.05$. Means of sinker fresh weight and percent germination were combined across concentrations and number of applications for each PGR and separated by the same procedure.

Several cases of differences between the number of applications within concentration were seen for seed number (Table 5). In all such cases the double application $(2 \mathrm{x})$ treatments gave lower seed numbers than the single application (1x) treatments. Few differences between concentration within number of applications were seen for seed number.

A few cases of differences between number of applications within concentration occurred for percent sinkers (Table 5). For antigibberellins uniconazole and daminozide at $1000 \mathrm{ppm}$, the double applications had higher percent sinkers, but for cytokinins 
Table 3. Effects of antigibberellins on seed trace development and germination of 'Mars', 'Reliance', and 'Saturn' grapes.

\begin{tabular}{|c|c|c|c|c|c|}
\hline $\begin{array}{l}\mathrm{PGR}^{\mathrm{z}} \\
(\mathrm{ppm})\end{array}$ & $\begin{array}{c}\text { Seed traces } \\
\text { per } 50 \\
\text { berries } \\
(\text { no. })^{\mathrm{y}}\end{array}$ & $\begin{array}{l}\text { Sinkers } \\
(\%)^{\mathrm{x}}\end{array}$ & $\begin{array}{l}\text { Sinker } \\
\text { fresh wt } \\
(\mathrm{mg})^{\mathrm{y}}\end{array}$ & $\begin{array}{c}\text { Germination } \\
(\%)^{\mathrm{x}}\end{array}$ & $\begin{array}{c}\text { Viable seeds } \\
\text { per } 50 \\
\text { berries } \\
(\text { no. })^{\mathrm{w}}\end{array}$ \\
\hline \multicolumn{6}{|c|}{ Mars } \\
\hline Chlormequat (500) & $71.5^{\mathrm{NS}}$ & $50.7 \mathrm{~b}$ & $3.7 \mathrm{bc}$ & $2.2^{\mathrm{NS}}$ & 36 \\
\hline Chlormequat (250) & 68.3 & $52.0 \mathrm{~b}$ & $4.5 \mathrm{bc}$ & 2.1 & 36 \\
\hline Ancymidol (100) & 69.3 & $46.6 \mathrm{bc}$ & $5.5 \mathrm{ab}$ & 1.6 & 32 \\
\hline Ancymidol (50) & 62.8 & $46.2 \mathrm{bc}$ & $3.0 \mathrm{c}$ & 0.0 & 29 \\
\hline Daminozide (500) & 68.5 & $31.8 \mathrm{~d}$ & $6.6 \mathrm{a}$ & 1.1 & 22 \\
\hline Daminozide (250) & 71.3 & $69.5 \mathrm{a}$ & $2.9 \mathrm{c}$ & 0.5 & 50 \\
\hline Control & 48.2 & $40.4 \mathrm{~cd}$ & $2.7 \mathrm{c}$ & 0.0 & 19 \\
\hline$P>\mathrm{F}$ & \multicolumn{5}{|c|}{ Reliance } \\
\hline Chlormequat (500) & $62.0 \mathrm{bc}$ & $18.6 \mathrm{~b}$ & $4.5^{\mathrm{NS}}$ & $0.0^{\mathrm{NS}}$ & 11 \\
\hline Chlormequat (250) & $74.5 \mathrm{bc}$ & $17.1 \mathrm{~b}$ & 5.1 & 0.0 & 13 \\
\hline Ancymidol (100) & $56.0 \mathrm{c}$ & $19.2 \mathrm{~b}$ & 4.3 & 0.0 & 11 \\
\hline Ancymidol (50) & $81.8 \mathrm{ab}$ & $19.9 \mathrm{~b}$ & 4.4 & 0.0 & 16 \\
\hline Daminozide (500) & $95.5 \mathrm{a}$ & $22.5 \mathrm{~b}$ & 2.1 & 0.0 & 21 \\
\hline Daminozide (250) & $74.5 \mathrm{bc}$ & $33.6 \mathrm{a}$ & 5.2 & 0.0 & 25 \\
\hline Control & $55.5 \mathrm{c}$ & $5.0 \mathrm{c}$ & 3.8 & 0.0 & 3 \\
\hline \multicolumn{6}{|c|}{ Saturn } \\
\hline Chlormequat (500) & $108.5 \mathrm{c}$ & $31.6 \mathrm{a}$ & $14.4^{\mathrm{NS}}$ & $16.9 \mathrm{a}$ & 34 \\
\hline Chlormequat (250) & $134.8 \mathrm{a}$ & $37.3 \mathrm{a}$ & 19.1 & $13.8 \mathrm{ab}$ & 50 \\
\hline Ancymidol (100) & $106.0 \mathrm{c}$ & $32.3 \mathrm{a}$ & 11.1 & $17.1 \mathrm{a}$ & 34 \\
\hline Ancymidol (50) & $111.0 \mathrm{c}$ & $34.5 \mathrm{a}$ & 9.8 & $11.8 \mathrm{~b}$ & 38 \\
\hline Daminozide (500) & $122.3 \mathrm{abc}$ & $37.3 \mathrm{a}$ & 12.2 & $8.8 \mathrm{bc}$ & 46 \\
\hline Daminozide (250) & $131.5 \mathrm{ab}$ & $34.4 \mathrm{a}$ & 12.5 & $6.3 \mathrm{c}$ & 45 \\
\hline Control & $118.0 \mathrm{bc}$ & $18.2 \mathrm{~b}$ & 15.0 & $8.9 \mathrm{bc}$ & 21 \\
\hline$P>\mathrm{F}$ & 0.0087 & 0.0017 & 0.1811 & 0.0020 & \\
\hline
\end{tabular}

${ }^{\mathrm{z}} \mathrm{PGR}=$ plant growth regulator; treatments were applied 2 weeks prebloom.

${ }^{y}$ Means within these columns separated by LSD at $P=0.05$.

xPercent data are weighted least squares means separated by multiple $t$ tests at $P=0.05$.

${ }^{\mathrm{w}}[($ Seed traces per 50 berries $\times$ percent sinkers $) / 100]$.

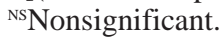

Table 4. Analysis of variance table for Expt. 4.

\begin{tabular}{|c|c|c|c|c|c|}
\hline & & $\begin{array}{c}\text { Seed traces } \\
\text { per } 50 \\
\text { berries } \\
\text { (no.) }\end{array}$ & $\begin{array}{c}\text { Sinkers } \\
(\%)\end{array}$ & $\begin{array}{l}\text { Sinker } \\
\text { fresh wt } \\
(\mathrm{mg})\end{array}$ & $\begin{array}{c}\text { Germination } \\
(\%)\end{array}$ \\
\hline Source & df & \multicolumn{4}{|c|}{$P>\mathrm{F}$} \\
\hline $\mathrm{PGR}^{\mathrm{z}}$ & 9 & 0.0001 & 0.0001 & 0.0107 & 0.0012 \\
\hline Concentration $(\mathrm{C})$ & 1 & 0.0047 & 0.5901 & 0.3769 & 0.1242 \\
\hline No. of applications (A) & 1 & 0.0001 & 0.0663 & 0.8205 & 0.8654 \\
\hline $\mathrm{PGR} \times \mathrm{C}$ & 9 & 0.0007 & 0.0211 & 0.5547 & 0.6938 \\
\hline $\mathrm{PGR} \times \mathrm{A}$ & 9 & 0.0026 & 0.0001 & 0.1791 & 0.0029 \\
\hline $\mathrm{C} \times \mathrm{A}$ & 1 & 0.5407 & 0.7827 & 0.3630 & 0.4961 \\
\hline $\mathrm{PGR} \times \mathrm{C} \times \mathrm{A}$ & 9 & 0.0005 & 0.0010 & 0.1791 & 0.1474 \\
\hline
\end{tabular}

${ }^{\mathrm{Z}} \mathrm{PGR}=$ plant growth regulator.

kinetin and BAP at 1000 ppm, the single applications had higher percent sinkers. A few cases of differences between concentration within number of applications also occurred for percent sinkers.

Since significant $F$ tests were obtained for the interaction of PGR $\times$ concentration $\times$ number of applications, individual treatment combinations were compared separately rather than as means of PGRs across both rates and number of applications for the variables of seed number and percent sinkers. Table 6 contains a list of the best treatment combination for each PGR for viable seed number on 'Venus'. The most effective treatment was a double application of uniconazole at 1000 ppm, which resulted in a 153\% increase over the control. 
Table 5. Effects of plant growth regulators (PGRs) at two rates and two applications on seed trace development and germination of 'Venus' grapes.

\begin{tabular}{|c|c|c|c|c|}
\hline $\begin{array}{l}\mathrm{PGR}^{\mathrm{z}} \\
\text { (ppm) } \\
\text { (no. of applications) }\end{array}$ & $\begin{array}{l}\text { Seed traces } \\
\text { per } 50 \\
\text { berries } \\
(\text { no. })^{\mathrm{y}}\end{array}$ & $\begin{array}{c}\text { Sinkers } \\
(\%)\end{array}$ & $\begin{array}{c}\text { Sinker fresh } \\
\text { wt } \\
(\mathrm{mg})\end{array}$ & $\begin{array}{c}\text { Germination } \\
(\%)\end{array}$ \\
\hline Chlormequat (2000) (1x) & $111.0 \mathrm{f}-\mathrm{m}$ & $38.4 \mathrm{i}-\mathrm{o}$ & & \\
\hline Chlormequat (2000) (2x) & $80.3 \mathrm{q}$ & $45.0 \mathrm{~b}-\mathrm{i}$ & & \\
\hline Chlormequat (1000) (1x) & $123.7 \mathrm{a}-\mathrm{f}$ & $44.3 \mathrm{~d}-\mathrm{i}$ & & \\
\hline Chlormequat (1000) (2x) & $119.2 \mathrm{c}-\mathrm{h}$ & $45.7 \mathrm{~b}-\mathrm{h}$ & $17.8 \mathrm{ab}^{\mathrm{x}}$ & $6.4 b^{x}$ \\
\hline Uniconazole (2000) (1x) & $136.0 \mathrm{a}$ & $49.5 \mathrm{~b}-\mathrm{e}$ & & \\
\hline Uniconazole (2000) (2x) & $118.3 \mathrm{~d}-\mathrm{j}$ & $52.0 \mathrm{~b}$ & & \\
\hline Uniconazole (1000) (1x) & $128.8 \mathrm{a}-\mathrm{d}$ & $47.9 \mathrm{~b}-\mathrm{g}$ & & \\
\hline Uniconazole (1000) $(2 x)$ & $127.8 \mathrm{a}-\mathrm{d}$ & $67.4 \mathrm{a}$ & $18.8 \mathrm{a}$ & $4.3 \mathrm{~b}$ \\
\hline Mepiquat chloride (2000) (1x) & $126.2 \mathrm{a}-\mathrm{e}$ & $42.1 \mathrm{~g}-\mathrm{m}$ & & \\
\hline Mepiquat chloride (2000) (2x) & $103.8 \mathrm{k}-\mathrm{n}$ & $44.0 \mathrm{~d}-\mathrm{j}$ & & \\
\hline Mepiquat chloride (1000) (1x) & $118.5 \mathrm{~d}-\mathrm{i}$ & $36.8 \mathrm{k}-\mathrm{p}$ & & \\
\hline Mepiquat chloride (1000) (2x) & $107.0 \mathrm{~h}-\mathrm{n}$ & $41.9 \mathrm{~g}-\mathrm{m}$ & $16.6 \mathrm{bc}$ & $7.3 \mathrm{~b}$ \\
\hline Ancymidol (264) (1x) & $134.3 \mathrm{ab}$ & $39.8 \mathrm{~h}-\mathrm{m}$ & & \\
\hline Ancymidol (264) (2x) & $105.5 \mathrm{i}-\mathrm{n}$ & $43.2 \mathrm{e}-\mathrm{k}$ & & \\
\hline Ancymidol (132) (1x) & $122.7 \mathrm{~b}-\mathrm{g}$ & $37.0 \mathrm{j}-\mathrm{O}$ & & \\
\hline Ancymidol (132) (2x) & $101.3 \mathrm{lmn}$ & $38.0 \mathrm{i}-\mathrm{o}$ & $16.1 \mathrm{bc}$ & $7.5 \mathrm{~b}$ \\
\hline $\mathrm{ABA}(10)(1 \mathrm{x})$ & $111.2 \mathrm{f}-\mathrm{m}$ & $40.6 \mathrm{~h}-\mathrm{n}$ & & \\
\hline $\mathrm{ABA}(10)(2 \mathrm{x})$ & 96.8 nop & $41.5 \mathrm{~g}-\mathrm{n}$ & & \\
\hline $\mathrm{ABA}(1)(1 \mathrm{x})$ & $116.3 \mathrm{~d}-\mathrm{k}$ & $41.8 \mathrm{~g}-\mathrm{m}$ & & \\
\hline $\operatorname{ABA}(1)(2 x)$ & $104.3 \mathrm{k}-\mathrm{n}$ & $44.0 \mathrm{~d}-\mathrm{j}$ & $16.1 \mathrm{bc}$ & $18.9 \mathrm{a}$ \\
\hline Daminozide (2000) (1x) & $114.0 \mathrm{e}-1$ & $44.8 \mathrm{c}-\mathrm{i}$ & & \\
\hline Daminozide (2000) (2x) & 94.3 nop & $40.4 \mathrm{~h}-\mathrm{n}$ & & \\
\hline Daminozide (1000) (1x) & $120.2 \mathrm{c}-\mathrm{g}$ & $41.9 \mathrm{~g}-\mathrm{m}$ & & \\
\hline Daminozide (1000) (2x) & $105.3 \mathrm{j}-\mathrm{n}$ & 50.6 bcd & $16.4 \mathrm{bc}$ & $7.4 \mathrm{~b}$ \\
\hline Kinetin $(2000)(1 \mathrm{x})$ & $116.3 \mathrm{~d}-\mathrm{k}$ & $42.6 \mathrm{f}-1$ & & \\
\hline Kinetin (2000) (2x) & $112.7 \mathrm{f}-1$ & $45.7 \mathrm{~b}-\mathrm{h}$ & & \\
\hline Kinetin (1000) (1x) & $123.5 \mathrm{a}-\mathrm{f}$ & $44.8 \mathrm{~d}-\mathrm{i}$ & & \\
\hline Kinetin (1000) (2x) & $110.7 \mathrm{f}-\mathrm{m}$ & $34.7 n-q$ & $15.7 \mathrm{c}$ & $14.7 \mathrm{ab}$ \\
\hline BAP (2000) (1x) & $113.3 \mathrm{e}-1$ & $44.9 \mathrm{c}-\mathrm{i}$ & & \\
\hline BAP (2000) (2x) & 99.3 mno & $44.5 \mathrm{~d}-\mathrm{i}$ & & \\
\hline BAP (1000) (1x) & $136.3 \mathrm{a}$ & $49.3 \mathrm{~b}-\mathrm{e}$ & & \\
\hline BAP (1000) (2x) & $85.5 \mathrm{pq}$ & $39.7 \mathrm{~h}-\mathrm{n}$ & $15.9 \mathrm{c}$ & $24.4 \mathrm{a}$ \\
\hline BTP (100) (1x) & $102.7 \mathrm{lmn}$ & $36.71-q$ & & \\
\hline BTP (100) (2x) & 86.3 opq & $29.5 \mathrm{pq}$ & & \\
\hline BTP (10) (1x) & $101.5 \mathrm{lmn}$ & $35.9 \mathrm{~m}-\mathrm{q}$ & & \\
\hline BTP (10) (2x) & 96.0 nop & $29.3 \mathrm{q}$ & $15.1 \mathrm{c}$ & $15.2 \mathrm{ab}$ \\
\hline 2iP (100) (1x) & $126.2 \mathrm{a}-\mathrm{e}$ & $48.9 \mathrm{~b}-\mathrm{f}$ & & \\
\hline $2 \mathrm{iP}(100)(2 \mathrm{x})$ & $105.8 \mathrm{i}-\mathrm{n}$ & $44.9 \mathrm{~b}-\mathrm{i}$ & & \\
\hline $2 \mathrm{iP}(10)(1 \mathrm{x})$ & $132.2 \mathrm{abc}$ & $51.4 \mathrm{bc}$ & & \\
\hline $2 \mathrm{iP}(10)(2 \mathrm{x})$ & 97.2 nop & $46.5 \mathrm{~b}-\mathrm{h}$ & $16.0 \mathrm{c}$ & $22.3 \mathrm{a}$ \\
\hline Control & $110.0 \mathrm{~g}-\mathrm{m}$ & $31.3 \mathrm{opq}$ & $16.4 \mathrm{bc}$ & $16.1 \mathrm{ab}$ \\
\hline
\end{tabular}

The results of some treatments applied to 'Venus' can be compared over 2 years. Seed number was about the same for control plots in both years (108.5 and 110.0 in 1989 and 1990, respectively). However, percent sinkers, sinker fresh weights, and percent germination differed for the 2 years. In 1989, controls had an average of $63 \%$ sinkers, but in 1990 the value was only $31 \%$. Sinker fresh weights for controls averaged $20.7 \mathrm{mg}$ in 1989 and $16.4 \mathrm{mg}$ in 1990. Germination percentages from controls averaged $7 \%$ in 1989 and $16 \%$ in 1990. Despite these differences, PGR effects were generally not different between years in terms of percent increase over the control. Weather conditions during bloom possibly caused the differences in percent sinkers and sinker fresh weight. The bloom period during the 1989 season was warmer and dryer than normal, whereas the bloom period during the 1990 season was cooler and wetter than normal. It has been observed that seed trace development in stenospermic grapes tends to be greater in hot, dry years. The differences in percent germination may be due to longer stratification times used in the 1990 study.

Sinker fresh weight was increased by PGRs in some experiments in 1989. It is assumed that larger, more developed seed traces would germinate better than smaller ones. Indeed, the 
Table 6. Effects of plant growth regulator (PGR) treatments on seed trace development and number of viable seeds of 'Venus' grapes.

\begin{tabular}{|c|c|c|c|c|}
\hline $\begin{array}{l}\mathrm{PGR}^{\mathrm{z}} \\
\text { (ppm) } \\
\text { (no. of applications) }\end{array}$ & $\begin{array}{l}\text { Seed traces } \\
\text { per } 50 \\
\text { berries } \\
\text { (no.) }\end{array}$ & $\begin{array}{c}\text { Sinkers } \\
(\%)\end{array}$ & $\begin{array}{l}\text { Viable seeds } \\
\text { per } 50 \\
\text { berries }^{y} \\
\text { (no.) }\end{array}$ & $\begin{array}{c}\text { Increase over } \\
\text { control }^{\mathrm{x}} \\
(\%)\end{array}$ \\
\hline Uniconazole (1000) (2x) & $127.8 \mathrm{a}$ & $67.4 \mathrm{a}$ & 86 & 153 \\
\hline $2 \mathrm{iP}(10)(1 \mathrm{x})$ & $132.2 \mathrm{a}$ & $51.4 \mathrm{~b}$ & 68 & 100 \\
\hline $\mathrm{BAP}(1000)(1 \mathrm{x})$ & $136.3 \mathrm{a}$ & $49.3 \mathrm{bc}$ & 67 & 97 \\
\hline Ancymidol (264) (1x) & $134.3 \mathrm{a}$ & $39.8 \mathrm{de}$ & 53 & 56 \\
\hline Chlormequat (1000) (1x) & $123.7 \mathrm{a}$ & $44.3 \mathrm{~cd}$ & 55 & 62 \\
\hline Kinetin $(1000)(1 \mathrm{x})$ & $123.5 \mathrm{a}$ & $44.8 \mathrm{~cd}$ & 55 & 62 \\
\hline Mepiquat chloride (2000) (1x) & $126.2 \mathrm{a}$ & $42.1 \mathrm{de}$ & 53 & 56 \\
\hline Daminozide (1000) $(2 x)$ & $105.3 \mathrm{~b}$ & $50.6 \mathrm{bc}$ & 53 & 56 \\
\hline $\mathrm{ABA}(1)(1 \mathrm{x})$ & $116.3 \mathrm{~b}$ & $41.8 \mathrm{de}$ & 49 & 44 \\
\hline BTP $(100)(1 \mathrm{x})$ & $102.7 \mathrm{~b}$ & 36.7 ef & 38 & 12 \\
\hline Control & $110.0 \mathrm{~b}$ & $31.3 \mathrm{f}$ & 34 & 0 \\
\hline
\end{tabular}

$\overline{{ }^{\mathrm{z}} \text { Means of the best treatment combination (concentration } \times \text { number of applications) for each PGR separated by LSD or multiple } t}$ tests at $P=0.05$.

$\mathrm{y}[($ Seed traces per 50 berries $\times$ percent sinkers $) / 100]$.

x[(Treatment mean no. viable seeds per 50 berries/control mean no. viable seeds per 50 berries $) \times 100]-100$.

relatively large seed traces of 'Venus' and 'Saturn' germinated fairly well compared to the small seed traces of 'Mars' and 'Reliance', which germinated poorly or not at all. However, sinker fresh weight does not seem to be directly related to germination percentage when comparing treatments on 'Venus' and 'Saturn'.

PGRs were successfully used to increase seed trace development in all stenospermic grape cultivars tested. Seed number and percent sinkers were increased to some extent for all cultivars tested. No particular treatment stood out as the best overall for all cultivars tested. Antigibberellins and cytokinins both gave positive results. The results suggest that specific PGRs and concentrations would need to be investigated for different genotypes to finetune the procedure.

Cultivars responded similarly to treatments for seed number and percent sinkers, but cultivars with naturally low seed numbers and percent sinkers ('Mars' and 'Reliance') were more responsive than those with naturally high numbers ('Venus' and 'Saturn'). Differences in the response of cultivars may be due to different inherent concentrations of naturally occurring PGRs among genotypes. The different seed trace development patterns of the cultivars studied may be related to these natural levels of PGRs.

The low germination rates among treatments and controls may be due to open pollination rather than controlled hybridizations. Outcrosses have been shown to have higher percentages of germination and seedling vigor than self or open pollinations on 'Venus' (Montes, 1985). Also, 'Venus' is an early ripening genotype, and germination percentages are typically low with these types.

Refinement of stratification and germination techniques should increase success in direct germination of seed traces. Ledbetter and Shonnard (1990), using similar techniques, found germination rates of up to $56 \%$ for stenospermic seed traces from the grape selection 'C $35-33$ ' after applying uniconazole at $240 \mathrm{ppm} 35$ days past budbreak compared to $12.4 \%$ germination in the control treatments. Although percent germination was variable and relatively low in this study, viable seed number and, consequently, the potential number of seedlings produced were greatly increased by applying PGRs. If a moderate percentage of induced seeds are germinable, PGR application could greatly increase the material to work with from controlled crosses. Despite of the failure of PGRs to greatly improve percent germination, increase in the viable seed number from seedless genotypes should improve efficiency in breeding programs using either embryo culture or direct germination procedures.

\section{Literature Cited}

Considine, J.A. 1983. Concepts and practice of use of plant growth regulating chemicals in viticulture, p. 89-183. In: L.G. Nickell (ed.). Plant growth regulating chemicals. vol. 1. CRC Press, Boca Raton, Fla. Considine, J.A. and B.G. Coombe. 1972. The interaction of gibberellic acid and 2-(chloroethyl) trimethyl ammonium chloride on fruit cluster development in Vitis vinifera L. Vitis 11:108-123.

Coombe, B.G. 1960. Relationship of growth and development to changes in sugars, auxins, and gibberellins in fruit of seeded and seedless varieties of Vitis vinifera. Plant Physiol. 35:241-250.

Coombe, B.G. 1965. Increase in fruit set of Vitis vinifera by treatment with growth retardants. Nature 205:305-306.

Emershad, R.L. and D.W. Ramming. 1984. In-ovulo embryo culture of Vitis vinifera L. cv. 'Thompson Seedless'. Amer. J. Bot. 71:873-877.

Iwahori, S., R.J. Weaver, and R.M. Pool. 1968. Gibberellin-like activity in berries of seeded and seedless 'Tokay' grapes. Plant Physiol. 43:333337.

Kender, W.J. and G. Remaily. 1970. Regulation of sex expression and seed development in grapes with 2-chloroethylphosphonic acid. HortScience 5:491-492.

Ledbetter, C.A. and D.W. Ramming. 1989. Seedlessness in grapes. Hort. Rev. 11:159-181.

Ledbetter, C.A., D.W. Ramming, and C.B. Shonnard. 1989. Fruiting characteristics and germination of the stenospermic grape selection 'C35-33' as affected by various plant growth regulators. Amer. Soc. Hort. Sci. Annu. Meeting/Program and Abstr. (Abstr. 100).

Ledbetter, C.A. and C.B. Shonnard. 1990. Fruiting characteristics and germination of the stenospermic grape selection 'C $35-33$ ' as affected by various plant growth regulators. J. Hort. Sci. 65:269-274.

Loomis, N.H. and J.H. Weinberger. 1979. Inheritance studies of seedlessness in grapes. J. Amer. Soc Hort. Sci. 104:181-184.

Milyaeva, E.L., N.K. Smirnova, and M.K.H. Chailakhyan. 1984. Hormonal regulation of female gametophyte development in seedless grape. Doklady Akademii Nauk SSSR 276:252-256, as cited in Plant Breeding Abstr. (1986) 56:880. (Abstr. 8183).

Montes, M.R.F. 1985. Studies on germination of seeds from early and late maturing grapes (Vitis spp.). MS thesis. Univ. of Arkansas, Fayetteville. Moore, J.N. 1970. Cytokinin-induced sex conversion in male clones of Vitis species. Proc. Amer. Soc. Hort. Sci. 95:387-393. 
Negi, S.S. and H.P. Olmo. 1966. Sex conversion in a male Vitis vinifera L. by a kinin. Science 152:1624-1625.

Nitsch, J.P., C. Pratt, C. Nitsch, and N.J. Shaulis. 1960. Natural growth substances in 'Concord' and 'Concord Seedless' grapes in relation to berry development. Amer. J. Bot. 47:566-576.

Pool, R.M. 1982. Effect of mepiquat chloride on the growth and yield of 'Concord' grapevines. J. Amer. Soc. Hort. Sci. 107:376-380.

Ramming, D.W. 1990. The use of embryo culture in fruit breeding. HortScience 25:393-398.

Spiegel-Roy, P., N. Sahar, J. Baron, and U. Lavi. 1985. In vitro culture and plant formation from grape cultivars with abortive ovules and seeds. J. Amer. Soc. Hort. Sci. 110:109-112.

Srinivasan, C. and M.G. Mullins. 1978. Control of flowering in the grapevine (Vitis vinifera L.): Formation of inflorescences in vitro by isolated tendrils. Plant Physiol. 61:127-130.
Srinivasan, C. and M.G. Mullins. 1979. Flowering in Vitis: Conversion of tendrils into inflorescences and bunches of grapes. Planta 145:187-192. Srinivasan, C. and M.G. Mullins. 1981. Induction of precocious flowering in grapevine seedlings by growth regulators. Agronomie 1:1-5.

Stout, A.B. 1936. Seedlessness in grapes. New York State Agr. Expt. Sta. (Geneva) Tech. Bul. 238.

Tukey, L.D. and H.K. Fleming. 1967. Alar, a new fruit-setting chemical for grapes. Pennsylvania Fruit News 46:12-31.

Weaver, R.J. 1972. Plant growth substances in agriculture. W.H. Freeman and Co., San Francisco.

Weaver, R.J., S.B. McCune, and C.R. Hale. 1962. Effect of plant regulators on set and berry development in certain seedless and seeded varieties of Vitis vinifera L. Vitis 3:84-96.

Weinberger, J.H. and F.N. Harmon. 1964. Seedlessness in vinifera grapes. Proc. Amer. Soc. Hort. Sci. 85:270-274. 